\title{
Properties of foamed concrete reinforced with hybrid fibres
}

\author{
Waleed Abbas ${ }^{1, *}$, Eethar Dawood ${ }^{2}$, and Yahya Mohammad $^{2}$ \\ ${ }^{1}$ Building and Construction Engineering Department, University of Technology, Iraq \\ ${ }^{2}$ Building and Construction Engineering Department, Technical College of Mosul, Iraq
}

\begin{abstract}
The properties of foamed concrete reinforced with carbon fibres and hybrid fibres of carbon with polypropylene fibres has been studied. Various volumetric fractions of carbon fibres $(0.5,1$ and $1.5 \%)$, hybrid fibres of carbon fibres (CF) with polypropylene fibres (PPF) as $(1 \% \mathrm{CF}+0.5 \% \mathrm{PPF}) \&(0.5 \% \mathrm{CF}+$ $1 \% \mathrm{PPF}$ ), also the mono polypropylene fibres as $1.5 \%$ PPF were used to reinforce foamed concrete mix. Fresh and hardened properties of all mixes included flowability, density, absorption, compressive strength, splitting tensile strength, and flexural strengths has been tested. Results showed that inclusion of carbon fibres up to $1 \%$ volumetric fraction may increase the compressive strength by about $36 \%$ higher than that of control mix. Whereas, the use of $1.5 \%$ carbon fibres exhibit significant increase in splitting and flexural tensile strengths by about 47 and $114 \%$, respectively, compared to the reference mix. On the other hand, the hybridization of $1 \% \mathrm{CF}+0.5 \% \mathrm{PPF}$ increased the splitting tensile strength and flexural strengths by $53 \%$ and $114 \%$, respectively, compared with plain foamed concrete mix.
\end{abstract}

Keywords: Foamed concrete, Carbon fibres, Hybrid fibres, Economical Efficiency

\section{Introduction}

Lightweight Foamed Concrete (LFC) can be represented as one of the recent advancement of concrete technology in civil engineering that can be used in a wide range of construction projects [1]. Significant improvements over the past 20 years in production equipment and betterquality surfactants (foaming agents) has enabled the use of foamed concrete on a larger scale [2].

The use of structural lightweight foamed concrete (SLWFC) which possesses good mechanical properties and durability ensures many advantages compared to normal weight concrete. Thus, SLWFC is a relatively new construction material which provides more efficient strength-to-weight ratio in structural elements [3]. Concrete has an inherently brittle nature and some disadvantages such as poor deformability and weak crack resistance in the practical usage. The fibers are used to improve the brittle nature of lightweight foamed concrete [4].

Fibers used in concrete can be classified into two types, Low modulus with high elongation fibers such as, polypropylene and polyethylene. this type has capable of large energy absorption properties and do not improve the compressive strength. On the other hand, high modulus with high strength fibers such as steel, glass and carbon produce strong composites [5].
The combination of different fibers may offer potential advantages in improving concrete properties. Hybrid fibers can provide reinforcement at all ranges of strains. Combination of low and high modulus fibers can arrest cracks at micro level as well as macro level [6].

Therefore, this study was prepared to induce carbon fibers and also combination of carbon and polypropylene fibers with foamed concrete. These different mixes are tested and evaluated from the view of economic efficiency.

\section{Materials and mix proportion}

\subsection{Materials}

The materials used in the present work are: cement, sand, water, silica fume foam agent, polypropylene fibers and carbon fibers.

Ordinary Portland cement (OPC) type (I) commercially known as AL-Mass cement factory (Sulaimaniyah governorate of Iraq) was used in this study. The physical characteristics of ordinary Portland cement is showed in Table 1 and conformed to IQS: 5/1984 [7]. Whereas the chemical compositions for the cement are shown in Table 2 and they conformed to ASTM C150 [8].

*Corresponding author: waleedalqaisi@yahoo.com 
Table 1. Physical properties of cements.

\begin{tabular}{|l|c|c|}
\hline Physical properties & Results & Limits of IQS: 5/1984[7] \\
\hline Initial setting time (minute) & 100 & $\geq 45$ \\
\hline Final setting time (minute) & 320 & $\leq 600$ \\
\hline Fineness (Blaine $\left.\mathrm{m}^{2} / \mathrm{kg}\right)$ & 300 & $\geq 230$ \\
\hline Soundness by Autoclave Method (\%) & 0.02 & Not more than 0.8 \\
\hline Compressive strength $(\mathrm{MPa})$ & 21 & $\geq 15$ \\
3 days & 27 & $\geq 23$ \\
7 days & & \\
\hline
\end{tabular}

Table 2. Chemical composition of cement.

\begin{tabular}{|c|c|c|c|}
\hline Composition & Abbreviation & Percentage by weight & Limits of IQS: $\mathbf{5 / 1 9 8 4 [ 7 ]}$ \\
\hline Lime & $\mathrm{CaO}$ & 61 & - \\
\hline Silica & $\mathrm{SiO}_{2}$ & 19.84 & - \\
\hline Alumina & $\mathrm{Al}_{2} \mathrm{O}_{3}$ & 5.08 & - \\
\hline Iron Oxide & $\mathrm{Fe}_{2} \mathrm{O}_{3}$ & 4.8 & - \\
\hline Sulphate & $\mathrm{SO}_{3}$ & 2.49 & $\leq 2.8$ \\
\hline Potash & $\mathrm{K}_{2} \mathrm{O}$ & 0.1 & \\
\hline Soda & $\mathrm{Na}_{2} \mathrm{O}$ & 0.3 & \\
\hline Equivalent $\mathrm{Na}_{2} \mathrm{O}$ & $\mathrm{Na}_{2} \mathrm{O}+0.658 \mathrm{~K}_{2} \mathrm{O}$ & 0.36 & $\leq 0.6 \%$ \\
\hline Magnesia & $\mathrm{MgO}$ & 2.48 & $\leq 5.0 \%$ \\
\hline Loss on ignition & L.O.I. & 3.8 & $\leq 4.0 \%$ \\
\hline Insoluble residue & I.R. & 0.40 & $\leq 1.5 \%$ \\
\hline \multicolumn{4}{|c|}{ Main Compounds (Bogue's equations) } \\
\hline Tri calcium Silicate & $\mathrm{C}_{3} \mathrm{~S}$ & 49.45 & - \\
\hline Di calcium Silicate & $\mathrm{C}_{2} \mathrm{~S}$ & 19.57 & - \\
\hline Tri calcium Aluminate & $\mathrm{C}_{3} \mathrm{~A}$ & 5.34 & - \\
\hline Tetra calcium Aluminate -Ferrite & $\mathrm{C}_{4} \mathrm{AF}$ & 14.61 & - \\
\hline
\end{tabular}

Silica fume (Sika Fume HR) was used as a partial replacement of cement, the material properties are shown in Table 3.

Table 3. Material properties of Silica fume.

\begin{tabular}{|l|c|}
\hline Form & Agglomerated \\
\hline $\begin{array}{l}\text { Particles Color/ } \\
\text { Appearance }\end{array}$ & Grey \\
\hline Specific Gravity & 2.20 \\
\hline Size of particles & $0.1 \mu$ \\
\hline Dosage & $2-10 \%$ by weight of cement \\
\hline Chloride content & Nil \\
\hline
\end{tabular}

The natural sand used as fine aggregate was supplied from AL- Ukhaider region. The specific gravity and fineness modulus of sand are 2.65 and 3, respectively. The grading limits are according to ASTM C 33-02 [9] and given in Table 4.

Sika Lightcrete 02 was used as a foaming agent to obtain lightweight foamed concrete by entraining a controlled amount of air bubbles to concrete mix. The foaming agent was diluted in 30 parts of water before using it. Carbon fibers with $8 \mathrm{~mm}$ length were used with the lightweight foamed concrete, the properties of the carbon fibers are listed in Table 5.
Table 4. Grading of fine aggregate.

\begin{tabular}{|c|c|c|}
\hline Sieve No. $(\mathbf{m m})$ & Passing (\%) & $\begin{array}{c}\text { Limits of ASTM C } \\
\text { 33-02[9] }\end{array}$ \\
\hline 4.75 & 95 & $95-100$ \\
\hline 2.36 & 80 & $80-100$ \\
\hline 1.18 & 59 & $50-85$ \\
\hline 0.6 & 44 & $25-60$ \\
\hline 0.3 & 18 & $5-30$ \\
\hline 0.15 & 4 & $0-10$ \\
\hline
\end{tabular}

Table 5. Properties of carbon fibers.

\begin{tabular}{|l|l|}
\hline Fiber properties & \multicolumn{1}{|c|}{ Quantity } \\
\hline Fiber length & $8 \mathrm{~mm}$ \\
\hline Diameter & $7 \pm 2$ micron \\
\hline Aspect ratio & 1140 \\
\hline Tensile strength & $3.5 \mathrm{GPa}$ \\
\hline Young's Modulus & $230 \mathrm{GPa}$ \\
\hline density & $1.7 \mathrm{~g} / \mathrm{cm}^{3}$ \\
\hline Chemical Resistance & $\mathrm{High}$ \\
\hline Absorption & $\mathrm{Nil}$ \\
\hline Melt Point & $3500^{\circ} \mathrm{C}$ \\
\hline Shape & chopped strand \\
\hline
\end{tabular}

Whereas, Monofilament polypropylene fibers (Sika fiber) were used in the lightweight foamed concrete mixes. Chopped strand shape fibers are $12 \mathrm{~mm}$ long with $18 \mu \mathrm{m}$ of diameter and density of $0.9 \mathrm{~g} / \mathrm{cm}^{3}$. The 
properties of the polypropylene fibers are listed in Table 6.

Table 6. Properties of polypropylene fibers.

\begin{tabular}{|l|l|}
\hline Fiber properties & \multicolumn{1}{|c|}{ Quantity } \\
\hline Fiber length & $12 \mathrm{~mm}$ \\
\hline Diameter & $18 \mathrm{microns}$ \\
\hline Aspect ratio & 670 \\
\hline Tensile strength & $500 \mathrm{MPa}$ \\
\hline Young's Modulus & $3.5 \mathrm{GPa}$ \\
\hline density & $0.9 \mathrm{~g} / \mathrm{cm}^{3}$ \\
\hline Chemical Resistance & $\mathrm{High}$ \\
\hline Absorption & Nil \\
\hline Melt Point & $160^{\circ} \mathrm{C}$ \\
\hline Shape & chopped strand \\
\hline
\end{tabular}

\subsection{Mix proportions}

The proportions of the foamed concrete mixes $(\mathrm{C} 0-\mathrm{C} 6)$ as shown in Table 7 were prepared using different volumetric fractions of fibers. However, the control or reference mix $(\mathrm{C} 0)$ has been prepared to be in the flowability range of $110 \pm 5 \%$.

Besides, the foamed concrete reinforced with carbon fiber mixes were designated by the mixes as $\mathrm{C} 1-\mathrm{C} 3$ due to the use of $0.5,1$ and $1.5 \%$ of carbon fibers, respectively. Thus, the flow value was recorded for each mix proportion.

Furthermore, the hybridizations of carbon fibers (CF) and polypropylene fibers (PPF) were presented in the mixes $\mathrm{C} 4-\mathrm{C} 5$. Such hybrid fibers were as $1 \% \mathrm{CF}+0.5 \%$ $\mathrm{PPF}$ and $0.5 \% \mathrm{CF}+1 \% \mathrm{PPF}$, respectively. And again, the flow test was done for these mixes.

Lastly, the use of $1.5 \%$ PPF was used to prepare the mix of C6. The flowability was also measured for this mix.

\section{Experimental work}

The molds of $100 \mathrm{~mm}$ cubes were used for testing the compressive strength of the foamed concrete mixes according to BS 1881 Part:116; 1983 [10]. The density and absorption for all mixes was also examined using 100 mm cubes according to ASTM C 642 [11]. The flexural strength of foamed concrete mixes was done using prismatic molds of $100 \times 100 \times 400 \mathrm{~mm}$ according to ASTM C78 [12]. Whereas, the cylindrical molds $100 \times 200 \mathrm{~mm}$ were used for splitting tensile strength according to ASTM C567 [13].

\section{Results and discussion}

\subsection{Effect of fibers on Flowability}

The effect of fibers on flow of the concrete mixes is depicted in Table 7 and Figure 1. It can be noticed that the inclusion of carbon fibers with foamed concrete mix reduces the flowability and thus, the flowability decreased from $110 \%$ to $60 \%$ due to $1.5 \%$ carbon fibers. On the other hand, each replacement of carbon fibers by polypropylene fibers leads to better flowability. In other words, the effect of polypropylene fibers on flowability or workability is much less than that of carbon fibers [14].

\subsection{Compressive strength}

Table 8 shows the results of compressive strength for specimens at ages of 7 and 28 days after water curing. The results of the compressive strength of foamed concrete mixes indicate that the increase in carbon fibers increases the compressive strength due to the reduction of porosity and an improvement in mechanical bond strength [15]. The percentage of compressive strength increase from using $1.0 \%$ of carbon fibers in the foamed concrete was about $35 \%$ for 28 days. However, the use of $1.5 \%$ reduces the percentage of the increase.

Alternatively, the results of the hybrid fibersspecimens also show that the use of $1 \% \mathrm{CF}+0.5 \% \mathrm{PPF}$ fibers gave higher value of compressive strength than that of $0.5 \% \mathrm{CF}+1 \% \mathrm{PPF}$, this is probably due to the ability of carbon fibers to enhance the ultimate strength capacity due to the higher stiffness of carbon fibers than that of polypropylene [16].

Figure 2 shows the percentages of increase of the compressive strength of foamed concrete due to different percentages of fibers.

Table 7. Mix proportions of foamed concrete mixes reinforced with fibers.

\begin{tabular}{|c|c|c|c|c|c|c|c|c|c|}
\hline \multirow{2}{*}{ Mixes } & \multicolumn{5}{|c|}{ Mix proportion } & \multicolumn{2}{|c|}{ fibers $\%$} & \multirow{2}{*}{$\begin{array}{c}\text { Flow } \\
\%\end{array}$} & \multirow{2}{*}{$\begin{array}{r}\text { Fresh } \\
\text { density } \\
\text { kg/m } / \mathbf{m}^{3}\end{array}$} \\
\hline & Cement & Sand & w/c \% & Silica fume & Foam kg/m & $\mathbf{C F}$ & PPF & & \\
\hline $\mathrm{CO}$ & 0.9 & 1.9 & 0.34 & 0.1 & 1 & $\begin{array}{ll}-- \\
\end{array}$ & --- & 110 & 1820 \\
\hline $\mathrm{C1}$ & 0.9 & 1.9 & 0.34 & 0.1 & 1 & 0.5 & --- & 80 & 1800 \\
\hline $\mathrm{C2}$ & 0.9 & 1.9 & 0.34 & 0.1 & 1 & 1 & --- & 75 & 1810 \\
\hline $\mathrm{C3}$ & 0.9 & 1.9 & 0.34 & 0.1 & 1 & 1.5 & --- & 60 & 1820 \\
\hline $\mathrm{C4}$ & 0.9 & 1.9 & 0.34 & 0.1 & 1 & 1 & 0.5 & 80 & 1800 \\
\hline $\mathrm{C5}$ & 0.9 & 1.9 & 0.34 & 0.1 & 1 & 0.5 & 1 & 80 & 1800 \\
\hline C6 & 0.9 & 1.9 & 0.34 & 0.1 & 1 & --- & 1.5 & 90 & 1800 \\
\hline
\end{tabular}


Table 8. Properties of foamed concrete mixes reinforced with fibers.

\begin{tabular}{|c|c|c|c|c|c|c|c|c|}
\hline \multirow{2}{*}{ Mixes } & \multicolumn{2}{|c|}{$\begin{array}{c}\text { Compressive strength } \\
\mathbf{M P a}\end{array}$} & \multicolumn{2}{c|}{$\begin{array}{c}\text { Splitting tensile } \\
\text { strength (MPa) }\end{array}$} & \multicolumn{2}{c|}{$\begin{array}{c}\text { Flexural strength } \\
\mathbf{( M P a )}\end{array}$} & $\begin{array}{c}\text { Absorption } \\
\mathbf{( \% )}\end{array}$ & $\begin{array}{c}\text { Oven dry density } \\
\mathbf{k g} / \mathbf{m}^{\mathbf{3}}\end{array}$ \\
\cline { 2 - 9 } & 7 Days & 28 Days & 7 Days & 28 Days & 7 Days & 28 Days & 28 Days & 28 Days \\
\hline C0 & 11.2 & 17.1 & 1.72 & 1.9 & 1.7 & 2.1 & 12.2 & 1670 \\
\hline C1 & 11.5 & 17.3 & 1.8 & 2.0 & 2.6 & 3.8 & 9.9 & 1745 \\
\hline C2 & 13.8 & 23.1 & 2.0 & 2.6 & 3.1 & 4.3 & 7.4 & 1805 \\
\hline C3 & 12.0 & 21.4 & 2.1 & 2.8 & 3.4 & 4.5 & 7.5 & 1820 \\
\hline C4 & 10.0 & 21 & 2.2 & 2.9 & 2.9 & 4.5 & 9.2 & 1775 \\
\hline C5 & 12.3 & 19.1 & 2.0 & 2.1 & 3.3 & 4.0 & 8.8 & 1770 \\
\hline C6 & 7.0 & 13.8 & 1.9 & 2.0 & 2.8 & 3.8 & 8.9 & 1715 \\
\hline
\end{tabular}

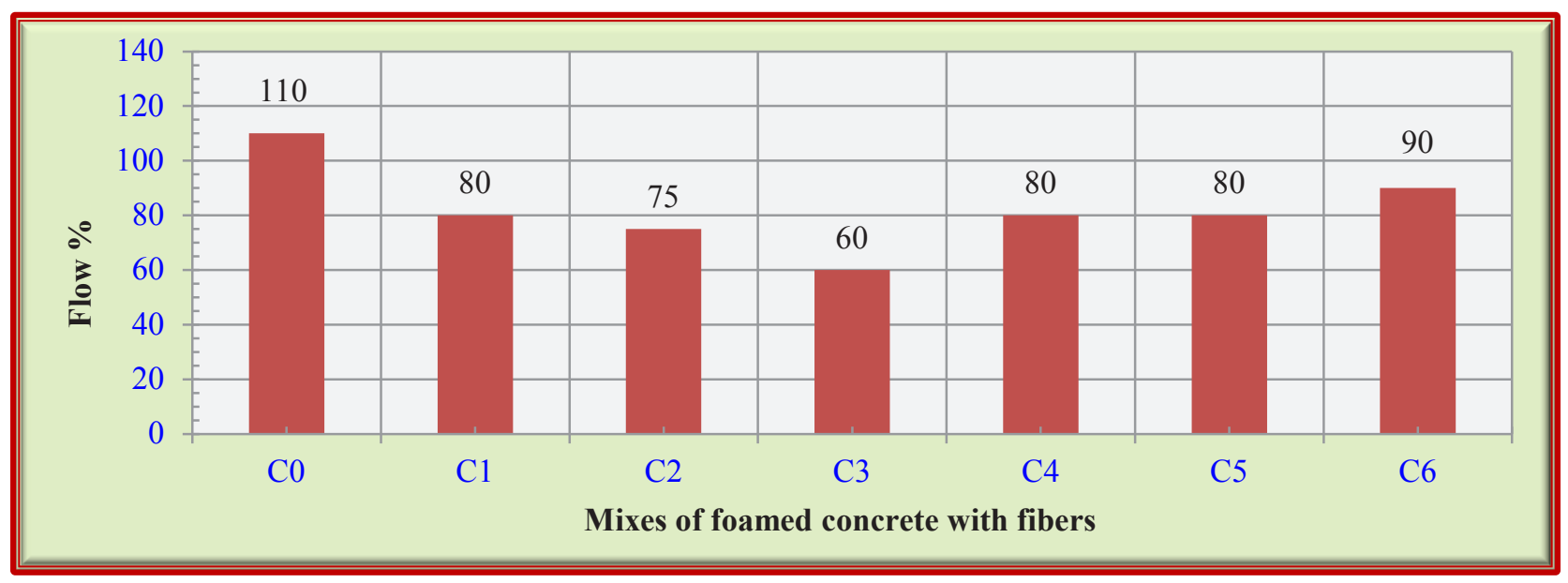

Fig. 1. Effect of fibers on the flow of the concrete mixes.

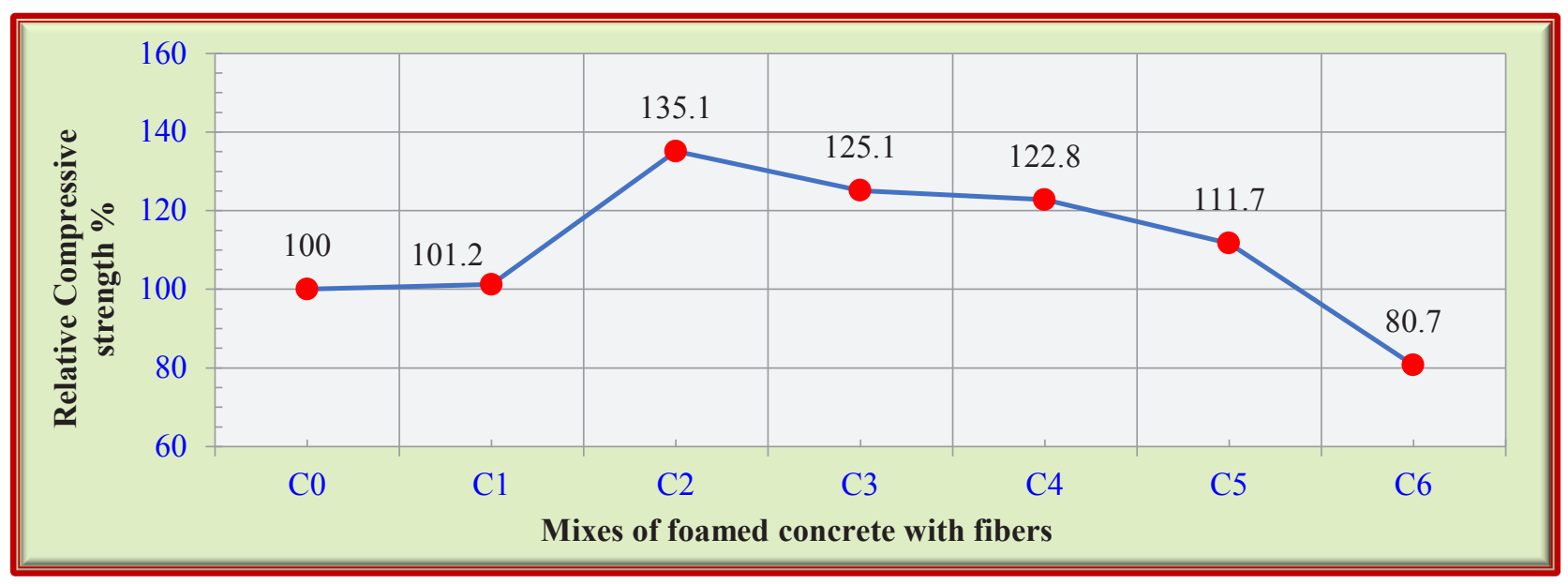

Fig. 2. Effect of fibers on the compressive strength for 28 days.

\subsection{Splitting Tensile Strength}

The results of splitting tensile strength for specimens at ages of 7 and 28 days after water curing are shown in Table 8.

The results show that the inclusion of carbon fibers in the foamed concrete mix increases the splitting tensile strength of foamed concrete. As the volumetric fraction of carbon fiber increases, the splitting tensile of foamed concrete increases, too.
Thus, the highest value recorded due to the use of $1.5 \% \mathrm{CF}$ in the foamed concrete mix and the percentage of increase is about $47 \%$ higher than that of reference foamed concrete for 28 days. This is related to the high tensile strength of carbon fibers that may promote the tensile strength of the foamed concrete and the ability of the fibers to arrest the cracks enhancing the homogeneity of the foamed concrete [17].

On the other hand, the hybridization of $1 \% \mathrm{CF}$ with $0.5 \%$ PPF increases the splitting tensile strength significantly. The percentage increases of the latter case 
(C4) was found to be higher than that of the control mix (C0) by about $53 \%$. This can be attributed to the ability of foamed concrete with two fibers to bridge the cracks effectively, thus, the micro-mechanical feature of cracks bridging is operative from the stage of damage evolution to beyond ultimate loading.

Figure 3 indicates the percentages of increase of the splitting tensile strength of foamed concrete due to different percentages of fibers.

\subsection{Flexural strength}

The results of flexural strength for specimens at ages of 7 and 28 days after water curing are shown in Table 8 .

The results of flexural strength of foamed concrete reinforced with carbon fibers show that the inclusion of fibers increases the flexural strength of foamed concrete. The highest value has been obtained due to the use of $1.5 \%$ carbon fiber in the foamed concrete mix and the percentage of increase is about $114 \%$ higher than that of plain foamed concrete.

Also, the hybridization of $1 \%$ CF with $0.5 \%$ PPF increases the flexural tensile strength significantly. The percentage increases by such use (C4) was also found to be higher than that of the control mix $(\mathrm{C} 0)$ by about $114 \%$.
This effective increase in flexural strength may have resulted from better compaction and homogenous distribution of fibers in mortar mixes and the ability of different types of fibers to restrain and bridge the cracks [18].

Figure 4 shows the percentages of increase of the flexural strength of foamed concrete due to different percentages of fibers.

\subsection{Absorption}

Table 8 shows the results of absorption for specimens at ages of 28 days after water curing.

It can be noted that the use of carbon fibers may significantly reduce the absorption of foamed concrete. The comparison between $\mathrm{C} 0$ with $\mathrm{C} 3$ shows that the use of $1.5 \%$ vol. of carbon fibers lowered the absorption from $12.2 \%$ to $7.5 \%$. This could be due to the fact that carbon fibers reduce the porosity of the foamed concrete by using these fibers [19].

On the other hand, the absorption reduction by using polypropylene fibers illustrates that these fibers have less ability to decrease the absorption than that of carbon fibers.

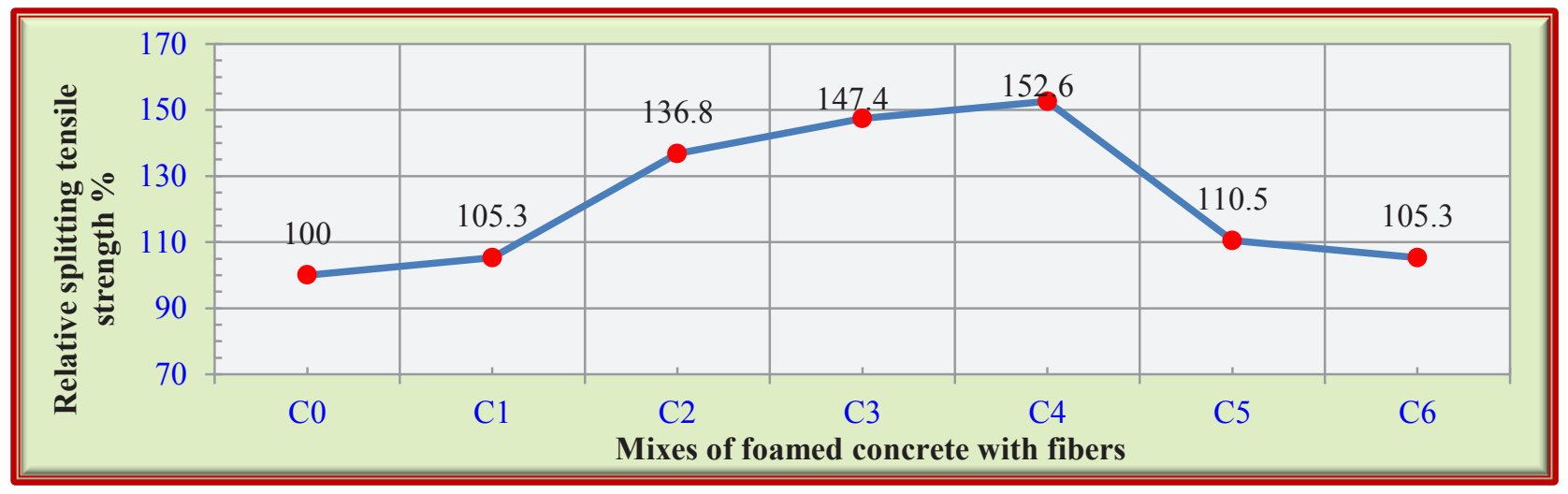

Fig. 3. Effect of fibers on the splitting tensile strength for 28 days.

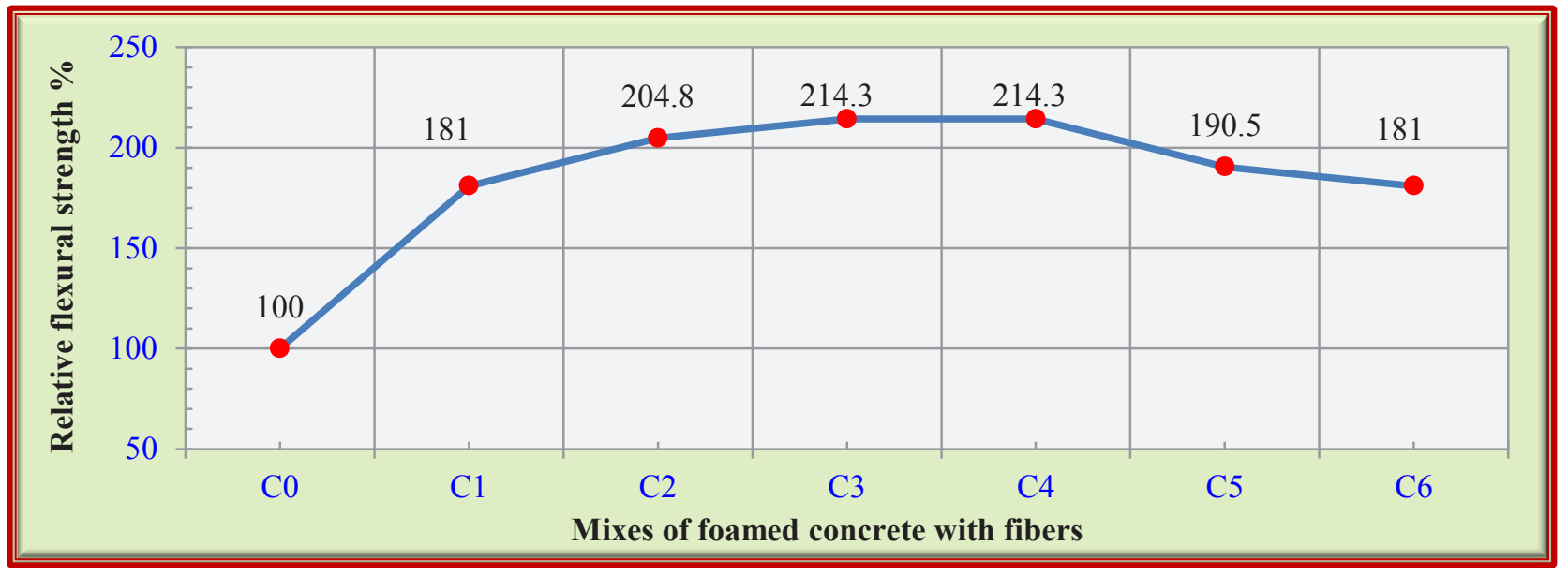

Fig.4. Effect of fibers on the flexural strength for 28 days. 


\subsection{Oven dry density}

Table 8 shows the results of absorption for specimens at ages of 28 days after water curing.

The test results of foamed concrete show that the increase in Carbon fibers leads to a significant increase in the oven dry density. The highest amount of carbon fibers used in the study $(1.5 \%)$ produces an increase in the density from $1670 \mathrm{~kg} / \mathrm{m}^{3}$ to $1820 \mathrm{~kg} / \mathrm{m}^{3}$. These results are also supported by other researchers [20]. Whereas, the unit weight of concrete increases with the increasing fiber content.

On the other hand, the effect of polypropylene fibers on the density of foamed concrete was found to be much less than that of carbon fibers. Therefore, the use of $1.5 \%$ of polypropylene fibers increases the density from $1670 \mathrm{~kg} / \mathrm{m}^{3}$ to $1715 \mathrm{~kg} / \mathrm{m}^{3}$.

\section{Economic Efficiency criteria}

Some logical steps were adopted to evaluate the performance of foamed concrete mixes reinforced with fibers and to study the economic efficiency of these fibers. For each mix, the cost of the mix per cubic meter of concrete was calculated. These steps are listed as follows:

Step1: Find the maximum value in each column as shown in Table 9.

Step2: Classify the columns into two types; maximum columns and minimum columns, according to the requirement of each property.

Step3: Find the coefficient for each value of the property, as shown in Table 10.

Step4: Find the average coefficient for each mix, the largest average coefficient presents the best mix.

Therefore, the results of the highest coefficient indicate that foamed concrete reinforced with hybrid fibers as $1 \% \mathrm{CF}+0.5 \% \mathrm{PPF}$ exhibit the best performance compared with other mixes. In other words, in-spite of the increase of the cost of foamed concrete by the inclusion of fibers, the enhancements obtained make this mix as the best effective one.

Also, the comparison between $\mathrm{C} 2$ and C6 illustrates that the use of $1.5 \% \mathrm{CF}$ is more effective than that of $1.5 \%$ PPF. So, the selection of costly fibers may be the suitable choice due to the requirements of the best performance.

Table 9. Maximum value for each property.

\begin{tabular}{|c|c|c|c|c|c|}
\hline Mixes & $\begin{array}{c}\text { Compressive strength } \\
\text { (MPa) 28 Days }\end{array}$ & $\begin{array}{c}\text { Splitting tensile strength } \\
\text { (MPa) 28 Days }\end{array}$ & $\begin{array}{c}\text { Flexural strength } \\
\text { (MPa) 28 Days }\end{array}$ & $\begin{array}{c}\text { Oven dry } \\
\text { density } \mathbf{~ k g} / \mathbf{m}^{\mathbf{3}}\end{array}$ & ${\mathbf{C o s t ~} \mathbf{\$} / \mathbf{m}^{\mathbf{3}}}$ \\
\hline C0 & 17.1 & 1.9 & 2.1 & 1670 & 100 \\
\hline C1 & 17.3 & 2.0 & 3.8 & 1745 & 121 \\
\hline C2 & 23.1 & 2.6 & 4.3 & 1805 & 143 \\
\hline C3 & 21.4 & 2.8 & 4.5 & 1820 & 164 \\
\hline C4 & 21.0 & 2.9 & 4.5 & 1775 & 147 \\
\hline C5 & 19.1 & 2.1 & 4.0 & 1770 & 130 \\
\hline C6 & 13.8 & 2.0 & 3.8 & 1715 & 114 \\
\hline $\begin{array}{c}\text { Maximum } \\
\text { value }\end{array}$ & $\mathbf{2 3 . 1}$ & $\mathbf{2 . 9}$ & $\mathbf{4 . 5}$ & $\mathbf{1 8 2 0}$ & $\mathbf{1 6 4}$ \\
\hline
\end{tabular}

Table 10. Coefficient calculation.

\begin{tabular}{|c|c|c|c|c|c|c|}
\hline \multirow{2}{*}{$\begin{array}{c}\text { Column type } \\
\text { Mix type }\end{array}$} & \multicolumn{3}{|c|}{$\begin{array}{l}\text { Maximum } \\
\text { (value / max. value from table 9) }\end{array}$} & \multicolumn{2}{|c|}{$\begin{array}{c}\text { Minimum } \\
1-(\text { value / max. value from table } 9)\end{array}$} & \multirow{2}{*}{$\begin{array}{l}\text { Average } \\
\text { coefficient }\end{array}$} \\
\hline & $\begin{array}{c}\text { Compressive } \\
\text { coefficient }\end{array}$ & $\begin{array}{c}\text { Splitting } \\
\text { coefficient }\end{array}$ & $\begin{array}{c}\text { Flexural } \\
\text { coefficient }\end{array}$ & $\begin{array}{c}\text { Oven dry density } \\
\text { coefficient }\end{array}$ & $\begin{array}{c}\text { Cost } \\
\text { coefficient }\end{array}$ & \\
\hline $\mathrm{C} 0$ & 0.74 & 0.66 & 0.47 & 0.08 & 0.39 & 0.47 \\
\hline $\mathrm{C} 1$ & 0.75 & 0.69 & 0.84 & 0.04 & 0.26 & 0.52 \\
\hline $\mathrm{C} 2$ & 1.00 & 0.90 & 0.96 & 0.01 & 0.13 & 0.60 \\
\hline $\mathrm{C} 3$ & 0.93 & 0.97 & 1.00 & 0.00 & 0.00 & 0.58 \\
\hline $\mathrm{C} 4$ & 0.91 & 1.00 & 1.00 & 0.02 & 0.10 & 0.61 \\
\hline $\mathrm{C} 5$ & 0.83 & 0.72 & 0.89 & 0.03 & 0.21 & 0.53 \\
\hline C6 & 0.60 & 0.69 & 0.84 & 0.06 & 0.31 & 0.50 \\
\hline
\end{tabular}




\section{Conclusions}

This paper describes the properties of foamed concrete reinforced with carbon and a combination of carbon fibers (CF) and polypropylene fibers (PPF). Some conclusions are observed as follows:

1. The use of carbon fibers may significantly decrease the flowability or workability of foamed concrete and have more effect than that of polypropylene fibers.

2. The use of $1 \%$ carbon fibers increases the compressive strength by about $36 \%$ compared with reference mix. Whereas, the use of $1.5 \%$ of carbon fibers increases the splitting and flexural strengths by about 44 and $116 \%$, respectively, compared with normal foamed concrete.

3. The hybridization of $1 \%$ CF with $0.5 \%$ PPF fibers improves the compressive strength by about $23 \%$ compared with reference mix. Whereas, the percentages of increase for splitting and flexural strengths are about 48 and $116 \%$, respectively, compared with normal foamed concrete.

4. The economical factor efficiency can be calculated to evaluate the mixes depending on best performance with least cost. Thus, the use of $1 \% \mathrm{CF}$ $+0.5 \%$ PPF fibers, gives the highest coefficient of such evaluation.

\section{Acknowledgements}

The work described in this paper is a part of Master research program of the $3^{\text {rd }}$ author. The authors express there thanks to the Building and Construction Department staff in the University of Technology-Baghdad for supporting their research. Special thanks to the technical staff in Concrete and Materials Lab in the department.

\section{References}

1. S.K. Lim, C.S. Tan, X. Zhao, T.C. Ling, K.S. of Civil Engineers, 19, 7, 2191-2197 (2015).

2. S.W. Dhengare, A.L. Dandge, H.R. Nikhade, J.I.A.A.T.S, 16 (2015).

3. O. A. EL-Nawawy, A.H. Zaher, A. A. Talaat, A. S. Mostafa, I.J.E.I.T, 4, 10 (2015).

4. N. K. Praful, I.J.T.E.E.E. 3, 4, (2015).

5. Yoo-Jae Kim, Jiong Hu, Soon-Jae Lee, Byung-Hee You, Hindawi Publishing Corporation Advances in Civil Engineering, Article ID 549642, 8 pages (2010)

6. J. S. Darole, V.P. Kulkarni, A.P. Shaikh, B.E. Gite I.J.E.R.A. 3, 4,1408-1411 (2013).

7. Iraqi Standard Specification (IQS), 5 (1984).

8. ASTM C 150, Annual book of ASTM standards, 04.01 (2007).

9. ASTM C 33, Annual book of ASTM standards, 04.02 (2002).

10. British Standard Institution, B.S. 1881, Part 116, (1983).
11. ASTM C 642, Annual book of ASTM standards, 04.02 (2006).

12. ASTM C78, Annual book of ASTM standards, 04.02 (2002).

13. ASTM C567, Annual book of ASTM standards, 04.02 (2000).

14. E.T. Dawood, M. Ramli, Construction and Building Materials, 25, 5, 2240-2247 (2011).

15. P.N. Balaguru, S.P. Shah, Fiber-Reinforced Cement Composites, Engineering series, McGraw-Hill International Editions (1992).

16. R.V. Balendran, F.P. Zhou, A. Nadeem, A.Y. Leung, Building and Environment 37, 12, 13611367 (2002).

17. E.T. Dawood, M. Ramli, Construction and Building Materials 28, 1, 193-200 (2012).

18. M. Sahmaran, I.O. Yaman, Construction and building materials 21, 1, 150-156 (2007).

19. G. E. Nawy, Fundamentals of high strength high performance concrete, Longman House, Burnt Hill, Harlow, England, (1996).

20. F. Koksal, F. Altun, I. Yigit, Y. Sahin, Construction and Building Materials 22, 8, 1874-1880 (2008). 